\title{
ТЕНДЕНЦІЇ МЕТОДИЧНОЇ ПІДГОТОВКИ МАЙБУТНІХ УЧИТЕЛІВ ПОЧАТКОВОЇ ШКОЛИ: МОВНО-ЛІТЕРАТУРНА ОСВІТНЯ ГАЛУЗЬ
}

\author{
OKSANA FENTSYK, Candidate of Pedagogical Sciences, AssociateProf., \\ Associate Professor at the Department of Theory and Methodologyof \\ Primary Education at Mukachevo State University, Ukraine
}

\section{TENDENCIES OF METHODICAL TRAINING OF FUTURE PRIMARY SCHOOL TEACHERS: LANGUAGE AND LITERARY EDUCATIONAL BRANCH}

Дослідження спрямоване на окреслення теоретичних засад підвищення якості методичної підготовки майбутніх учителів початкової школи до проведення уроків мовно-літературної освітньої галузі в умовах освітнього середовища НУШ.

На підставі грунтовного аналізу наукових позицій подано визначення дефініції професійна підготовка вчителя початкової школи. Визначено, що важливою складовою професійної є методична підготовка вчителя початкової школи в закладах вищої освіти до навчання різних освітніх галузей початкової школи (мовно-літературної, математичної, природничої тощо). З'ясовано, що результатом професійної та методичної підготовки є сформована професійнометодична компетентність. Схарактеризовано поняття професійної та лінгвометодичної компетентності.

Закцентовано увагу на особливостях методичної підготовки в галузі мовно-літературної освіти. Стисло окреслено моніторинг професійно-методичної готовності студентів четвертих курсів Мукачівського державного університету до проведення особистісно зорієнтованого уроку української мови в умовах інноваційного освітнього середовища НУШ. Обгрунтовано потребу вдосконалення процесу методичної підготовки (мовно-

(c) О. Фенцик літературної освітньої галузі) майбутніх учителів початкової школи під час навчання в закладах вищої освіти. Критичне осмислення поглядів науковців, аналіз змісту освітньо-професійної програми підготовки 013 Початкова освіта, узагальнення методів опитування дозволили автору визначити мету й розглянути тенденції удосконалення методичної підготовки майбутніх учителів початкової до проведення уроків мовно-літературної освітньої галузі в умовах освітнього середовища НУШ.

Ключові слова: професійна підготовка, методична підготовка, заклад вищої освіти, методична компетентність, мовно-літературна освітня галузь, інноваційне освітнє середовище, Нова українська школа.

Summary. The research has been aimed at identifying the theoretical bases of improvement of quality of methodical preparation of future primary school teachers to conduct lessons of language and literature educational branch in the conditions of educational environment of the New Ukrainian School.

On the basis of a thorough analysis of scientific positions, the author has presented the definition of "vocational training of primary school teachers". It has been determined that an important component of the professional training is the methodical preparation of primary school teachers in higher educational institutions for teaching various educational fields of elementary school (linguistic, literary, mathematical, natural, etc.). It has been found that the result of professional and methodological training is formed professional and methodological competence. The author of the article has considered the sense of the conceptions of professional and methodical competence.

Attention has been paid at the peculiarities of methodological training in the field of language and literary education. The results of the monitoring of the vocational and methodological readiness of the students of the fourth year of Mukachevo State University to conduct a personally oriented lesson of the Ukrainian language in the conditions of the innovative educational environment of New Ukrainian School have been presented. We have substantiated the need to improve the process of methodological training (language and literary educational field) of future primary school teachers during the study at higher educational establishment. Critical reflection on the views of scientists, analysis of the content of educational and professional training program 013 Primary education, generalization of survey methods have allowed the author to determine the purpose and to consider the tendencies of improving the methodological 
training of future primary school teachers to conduct lessons of language and literary educational field in the conditions of educational environment og the New Ukrainian School.

Key words: vocational training, methodological training, higher educational establishment, methodical competence, language and literary educational field, development of younger students' personality by means of various types of speech activity, communicative, reading competence, innovative educational environment, New Ukrainian School.

Мета: окреслити тенденції удосконалення методичної підготовки майбутніх учителів початкової школи до проведення уроків мовно-літературної освітньої галузі в умовах освітнього середовища НУШ.

Постановка проблеми в загальному вигляді. Модернізація сучасної освіти в Україні, упровадження Концепції "Нова українська школа" спонукає науковців здійснювати пошук ефективної моделі професійної підготовки педагогів у закладах вищої педагогічної освіти. Не викликає сумніву те, що реалізація завдань Концепції Нової української школи буде успішною, якщо вже на етапі початкової освіти працюватиме творчий учитель, готовий до створення комфортного освітнього середовище на інноваційних засадах, адже саме на нього покладається супровід розвитку та формування компетентного випускника початкової ланки освіти, який здатний до життя в суспільстві та має прагнення до самовдосконалення і навчання впродовж життя.

У структурі професійної підготовки педагога важливою є якісна методична підготовка, оскільки йдеться про формування професійної компетентності до навчання дев'яти освітніх галузей. Це особливо важливо, у випадку методичної підготовки майбутнього вчителя початкових класів до проведення уроків мовно-літературної освітньої галузі, оскільки саме йому належиться формувати "вміння читати і розуміти прочитане, уміння висловлювати власну думку усно і письмово, здатність логічно обгрунтовувати позицію" (Кон- цепиія "Нова українська школа", 2018), які відповідно до Концепції Нової української школи визначено як наскрізні, що створюють основу для успішної самореалізації учня як особистості і громадянина. Разом з тим першою в переліку формування ключових компетентностей - "вільне володіння державною мовою, що передбачає уміння усно й письмово висловлювати свої думки, почуття, чітко та аргументовано пояснювати факти, а також любов до читання, відчуття краси слова, усвідомлення ролі мови для ефективного спілкування та культурного самовираження, готовність вживати українську мову як рідну в різних життєвих ситуаціях" (Концееція "Нова українська школа", 2018). Цілком зрозуміло, що формування ключових та визначених наскрізних умінь учні набувають під час вивчення різних предметів на всіх етапах освіти. Проте початкова освіта $є$ фундаментом формування, що здійснюється, насамперед, у процесі вивчення предметів мовнолітературної освітньої галузі.

Аналіз останніх досліджень і публікацій. Педагогічні дослідження $з$ проблеми характеристики професійної компетентності вчителя початкових класів висвітлено у працях В. Бондар, Н. Бібік, О. Біда, П. Гусак, Л. Хомич, Л. Хоружа, І. Шапошнікова та інших. Актуальні питання підготовки майбутнього вчителя початкової школи до реалізації завдань математичної освітньої галузі стали предметом вивчення Н. Глузман, Л. Коваль, С. Скворцової та ін.; до реалізації завдань мистецької освіти - О. Красовської, Ю. Ростовської, О. Хомік; методичну компетентність у навчанні природничої освітньої галузі висвітлили А. Бальоха, І. Вікторенко, І. Жаркова, С. Приходько.

Лінгвометодичні засади моделювання уроків мовно-літературної освітньої галузі (українська мова та літературне читання) у початковій школі презентовано в наукових доробках М. Вашуленка, В. Мартиненко, В. Науменко, К. Пономарьової, О. Савченко. Водночас аналіз наукового фонду досліджень дозволив констатувати, що безпосередньо методична підготовка майбутніх учителів початкової школи до проведення уроків мовно-літературної освітньої га- лузі на засадах інноваційного підходу до організації освітнього процесу залишаються переважно поза увагою дослідників.

Виклад основного матеріалу дослідження. Розгляд окресленої проблеми розпочнемо з аналізу поняття професійна підготовка вчителя початкових класів. Сучасна теорія накопичила значний науковий фонд, де розкрито зміст дефініції професійна підготовка. Зокрема, у Законі України "Про освіту" статті 58 вжито термін підготовка: "Педагогічна освіта передбачає підготовку особи, результатом якої $є$ набуття компетентностей зі спеціальності (предметної спеціальності, спеціалізації), педагогіки, психології, у тому числі шляхом проходження педагогічної практики, необхідних для забезпечення процесу навчання, виховання і розвитку особистості, у тому числі осіб з особливими освітніми потребами, моніторингу педагогічної діяльності та аналізу педагогічного досвіду, проведення освітніх вимірювань, застосування освітніх технологій і методів навчання, ефективних способів взаємодії всіх учасників освітнього процесу" (Закон України "Про освіту", 2017). Вітчизняна дослідниця Н. Ничкало вказує, що професійна підготовка орієнтована на особистісний розвиток і творчу самореалізацію кожного громадянина України, формування поколінь, які навчаються впродовж життя, розвивають цінності громадянського суспільства, сприяють консолідації української нації та її інтеграції до європейського і світового простору (Ничкало, 2001, с. 10). На думку Л. Хоружи, професійна підготовка майбутнього вчителя в широкому значенні - це сукупність теоретичних знань, практичних умінь, досвіду та особистісних якостей учителя, діалектичний перебіг яких забезпечує ефективність і результативність педагогічної дії (Хoружа, 2004, с.18). Досліджуючи аспекти професійної підготовки вчителя початкових класів, Л. Хомич зазначає, що "це процес навчання студентів 3 психолого-педагогічних дисциплін, у навчальнопрактичній та науково-дослідній роботі. Усі дисципліни психологопедагогічного циклу в комплексі повинні визначати професійну спрямованість педагогічного зак- 
ладу, бути ядром професійної підготовки студентів" (Хомич, 1998, c. 3).

На підставі грунтовного вивчення поглядів науковців (Бондар \& Шапошнікова, 2015; Кучеренко, 2014 ma ін.) професійну підготовку вчителя початкової школи" визначаємо як цілісний динамічний процес засвоєння психолого-педагогічних і методичних знань, формування умінь, навичок, розвиток особистісних та формування професійних якостей, цінностей, набуття початкового досвіду педагогічного проєктування, вирішення педагогічних задач, метою і кінцевим результатом цього процесу $\epsilon$ сформований "комплекс якостей особистості, що виявляються у здатності продуктивно організувати освітній процес у початковій загальноосвітній школі відповідно до сучасних вимог на засадах особистісно зорієнтованого, діяльнісного та інтегрованого підходів" (Феничик, 2018, с.200); готовності до інноваційно-творчого виконання майбутньої професійної діяльності в умовах освітнього процесу НУШ.

Методична підготовка як компонент цілісної системи професійної підготовки полягає у формуванні готовності майбутніх педагогів до навчання різних освітніх галузей початкової школи (мовнолітературної, математичної, природничої тощо), а її результатом $\epsilon$ сформована методична компетентність.

Методичну компетентність майбутніх учителів початкової школи до навчання мовно-літературної освітньої галузі називаємо лінгвометодичною компетентністю, яку розуміємо як комплекс якостей майбутнього фахівця, що відображає рівень знань сформованих умінь, навичок, цінностей, набутого початкового досвіду вирішення методичних задач, що необхідні для готовності та здатності творчо розв'язувати професійні завдання, які необхідні для якісного проєктування, моделювання уроків мовно-літературної освітньої галузі, здійснення на цих уроках продуктивної процесуальнотехнологічної діяльності, а також здатності до самооцінки та саморозвитку з урахуванням нормативних вимог, що постійно змінюються (Фенцик, 2018, с. 201).

Як зазначено в Державному стандарті початкової загальної освіти, "мовно-літературна освітня галузь включає українську мову та літературу, мови та літератури відповідних корінних народів і національних меншин, іншомовну освіту" (Державний стандарт початкової освіти, 2018). Змістом нашої наукової розвідки є аспект методичної підготовки майбутніх учителів початкових класів до реалізації завдань мовно-літературної освітньої галузі: українська мова та література (читання(1-2 класи) та (літературне читання 3-4 класи), метою і результатом якої є сформованість лінгвометодична компетентність.

Розв'язання проблеми якісної професійно-методичної підготовки вчителя початкових класів до реалізації завдань мовно-літературної галузі відповідно до Державного стандарту початкової загальної освіти та Концепції Нової української школи вимагає глибокого усвідомлення переваг особистісно орієнтованої парадигми освіти, компетентнісного творчо-інноваційного підходу до організації освітнього процесу, мовно-мовленнєвої та читацької грамотності, комунікативної та професійно-методичної компетентності.

3 метою визначення рівня професійно-методичної готовності майбутнього вчителя до проведення особистісно зорієнтованого уроку української мови в умовах інноваційного освітнього середовища НУШ провели моніторинг серед студентів четвертих курсів спеціальності 013 "Початкова освіта" Мукачівського державного університету. Моніторинг включав комплекс дослідницьких процедур: методи опитування, педагогічне спостереження, аналіз продуктів творчої діяльності студентів. Було виокремлено чотири компоненти для визначення рівня готовності студентів до проведення уроків мовно-літературної освітньої галузі (українська мова) у початковій школі: мотиваційно-ціннісний (виявляється у мотивах, цілях, цінностях, що спонукають майбутніх педагогів до вдосконалення власної мовленнєвої майстерності, комунікативної та читацької, літературознавчої компетентностей та формування мовленнєвої та читацької грамотності учнів), змістовий (сукупність лінгвістичних, мовленнє- вих, літературознавчих, психологопедагогічних і методичних знань); процесуальний (сукупність умінь i навичок щодо розвитку особистості молодших школярів засобами різних видів мовленнєвої діяльності, формування в них комунікативної та читацької компетентностей), рефлексивно-оцінювальний компонент (здатність до оцінювання своєї професійно-методичної діяльності, здатність до рефлексії, саморозвитку). Усі вони взаємодіють та впливають один на одного. Високий рівень реалізації цих компонентів та стійке їх поєднання відображають внутрішні ознаки сформованої професійно-методичної готовності майбутнього вчителя початкових класів як до педагогічної діяльності в цілому, так $\mathrm{i}$, зокрема, до проведення уроків мовно-літературної освітньої галузі в умовах освітнього середовища нової української школи. Студентам також було запропоновано проаналізувати й оцінити свою професійно-методичну готовність у галузі мовно-літературної освіти. Високий рівень готовності відмітили $20 \%$ осіб, середній - 50\%, початковий - 30\%. Отже, результати комплексного вивчення стану професійно-методичної готовності майбутніх учителів початкових класів до проведення уроків мовно-літературної освітньої галузі в умовах інноваційного освітнього середовища НУШ засвідчили недостатній рівень їі сформованості.

Процес методичної підготовки майбутнього вчителя початкової школи в галузі мовно-літературної освіти в цілісній системі професійної "включає педагогічне цілепокладання, зміст освіти, методи, засоби, технології досягнення поставленої мети, а також студента як суб'єкта соціально-педагогічного процесу та викладача як організатора цього процесу" (Будник, 2014, с. 55).

Критичне осмислення міркувань науковців, аналіз змісту освітньо-професійної програми підготовки 013 Початкова освіта першого і другого рівнів, узагальнення методів опитування серед студентів, учителів початкових класів дозволило насамперед, визначити мету й тенденції удосконалення методичної підготовки майбутніх учителів початкової школи до про- 
ведення уроків мовно-літературної освітньої галузі в умовах освітнього середовища НУШ.

Мета професійно-методичної підготовки (мовно-літературна освітня галузь: українська мова) полягає у засвоєнні майбутніми вчителями початкової школи системи знань (з лінгвістики, дитячої літератури та основ літературознавства, психології та педагогіки, методики і технології навчання), формуванні відповідних умінь, навичок, особистісних і професійних якостей, культурно-мовних, педагогічних цінностей, набутті початкового досвіду їх практичного застосування, що дозволить забезпечити процесуально-технологічну готовність майбутніх учителів початкових класів до ефективного проведення особистісно зорієнтованого уроку української мови та закладе здатність здійснювати процес "розвитку особистості молодших школярів засобами різних видів мовленнєвої діяльності, формувати комунікативну, читацьку компетентності, розвивати мовленнєво-творчі уміння учнів" (Державний стандарт початкової освiти, 2018) в умовах інноваційного освітнього середовища Нової української школи.

Опитування студентів щодо їх готовності до проведення уроків мовно-літературної галузі в умовах комунікативно-пізнавального середовища Нової української школи дозволив виокремити такий важливий напрям, як удосконалення змісту професійної підготовки.

Професійна (методична) підготовка майбутніх учителів початкових класів до проведення уроків мовно-літературної освітньої галузі відбувається через систему вивчення дисциплін професійнопедагогічного спрямування і практичну підготовку. Наприклад, у Мукачівському державному університеті до таких дисциплін віднесено: "Українська мова за професійним спрямуванням", "Сучасна українська мова 3 практикумом", "Методика навчання української мови з каліграфією", "Основи культури і техніки мовлення / Виразне читання" (освітньо-професійної програми "Початкова освіта" першого (бакалаврського) рівня вищої освіти) та "Технології навчання мовно-літературної освітньої галузі", "Педагогічна комунікація" (освітньо-професійної програми "Початкова освіта" другого (магістерського) рівня вищої освіти). У процесі аналізу змісту програм ми дійшли висновку, що фактично кожна 3 навчальних дисциплін загальної і професійної складової містить (більшою чи меншою мірою) змістові ресурси, необхідні для розвитку мовленнєвих знань, умінь, навичок та компетентностей самих студентів, що є важливим чинником мовленнєвого розвитку молодших школярів, а відтак формування мовленнєвої компетенції. Водночас, як вказують результати нашого опитування, цей комплекс дисциплін не є достатнім для формування високого рівня готовності до реалізації завдань мовно-літературної освітньої галузі та практичного використання інноваційних методик (технологій) навчання, виховання та розвитку учнів молодшого шкільного віку в умовах освітнього процесу Нової української школи.

Закономірно, що зміст професійної (методичної) підготовки необхідно оновити відповідно до Державного стандарту початкової загальної освіти, оскільки його змістова частина (мовно-літературна освітня галузь) та типові освітні програми для НУШ зазнали істотних змін. Важливо до освітніх програм професійної підготовки студентів спеціальності 013 "Початкова освіта" включити такі дисципліни вільного вибору: для першого (бакалаврського) рівня - "Технологія дослідження мовних явищ в умовах комунікативно-пізнавального середовища Нової української школи", "Технологія формування медіаграмотності та критичного мислення на уроках літературного читання", "Технологія формування читацької грамотності"; а для другого (магістерського) рівня вищої освіти - "Моделювання особистісно зорієнтованих уроків мовно-літературної освітньої галузі для НУШ", "Методична компетентність вчителя початкових класів: мовно-літературна освітня галузь", зміст яких спрямований на формування професійно-методичних компетентностей майбутніх учителів початкових класів відповідно до Концепції "Нова українська школа" та Державного стандарту початкової освіти.
Також важливим аспектом у системі професійно-методичної підготовки майбутніх учителів початкової школи є впровадження інноваційних технологій навчання у закладах вищої освіти та створення комунікативно-освітнього середовища на засадах партнерства.

Безсумнівно, що ефективність процесу методичної підготовки майбутніх учителів початкової школи до навчання молодших школярів мовно-літературної освітньої галузі здебільшого залежить від методики викладання дисциплін мовно-літературної освіти. Створення інноваційного освітнього середовища, упровадження на заняттях інтерактивних, продуктивно-творчих, проблемно-дослідницьких технологій повинно бути спрямоване на забезпечення самореалізації особистості, формування професійної компетентності майбутнього вчителя початкової школи в мовно-літературній освітній галузі. Тому на заняттях 3 методики викладання дисциплін мовно-літературної освіти необхідно надавати пріоритету інтерактивним, інформаційно-комунікативним, проєктним, проблемним, дослідницьким технологіям. Зокрема, доцільними бачаться лекціявізуалізація, проблемна лекція, інтерактивна лекція, адже діалогічна ситуація на лекціях, що створюється шляхом проблемного викладу матеріалу, спонукає студентів до діалогу з викладачем, концентрує увагу на ключових питаннях лекції, активізує процес засвоєння. Важливе значення має створення комунікативно-пізнавального середовища у процесі викладання фахових методик, якому сприяють групові та індивідуальні бесіди, дискусії, синтез думок, вирішення комунікативних та методичних задач, ділові ігри, тренінги, методичний проєкт тощо. Аудиторні заняття повинні передбачати моделювання професійно спрямованих ситуацій, обговорення науковометодичних проєктів, моделювання уроків за різними технологіями у групах, які допомагають відтворювати фахові ситуації, "занурювати" студентів в активне контрольоване спілкування, де вони виявляють свою сутність і взаємодіють 3 іншими, розвивають комунікативні здібності, вчаться стримувати емоції та почуття, конструк- 
тивно вирішувати конфлікти, будувати взаємини на основі поваги та партнерства.

Окрім зазначених вище тенденцій, як свідчить безпосереднє опитування не тільки студентів, але й учителів початкових класів, важливими напрямами вдосконалення методичної підготовки майбутніх учителів початкової школи є: формування мотиваційної спрямованості педагога на безперервне професійно-методичне самовдосконалення; створення навчально-рефлексивного середовища на заняттях 3 методики навчання мовнолітературної освітньої галузі; продумана організація самостійної роботи, пошуково-дослідницької діяльності в системі методичної підготовки майбутнього вчителя початкових класів до навчання української мови.

Висновки та перспективи подальших досліджень. Підсумовуючи, варто зазначити: у контексті упровадження Концепції "Нова українська школа" професійно-методична підготовка поступово повинна наповнюватись позитивними змінами, які є надзвичайно важливими у формуванні професійнометодичної компетентності вчителя. Адже рівень сформованості ключових та наскрізних умінь, комунікативної та читацької компетентностей випускників початкової освіти залежить від готовності майбутнього вчителя початкової школи самостійно проєктувати та моделювати технологічний процес навчання на уроках мовно-літературної освітньої галузі відповідно до сучасних вимог, проводити особистісно зорієнтовані уроки української мови на засадах компетентнісного та інтегративного підходів, їх здатності створити на уроках комунікативне навчально-пізнавальне освітнє середовище на засадах партнерства; готовності здійснювати рефлексію педагогічної діяльності з метою самооцінювання та професійного саморозвитку.

Перспективою подальшого дослідження вважаємо представлення експериментально перевіреної моделі методичної підготовки майбутніх учителів початкової школи до створення інноваційного освітнього середовища на уроках мовно-літературної освітньої галузі відповідно до вимог Концепції Нової української школи.

\section{СПИСОК ЛІТЕРАТУРИ}

Бондар, В. І., Шапошнікова, I. M. (2015). Управління підготовкою успішного вчителя: теорія і практика. Київ : НПУ Драгоманова.

Будник, О. (2014). Теоретичні концепти підготовки майбутніх учителів до соціально-педагогічної діяльності у школі І ступеня. Педагогіка і психологія професійноӥ освіти, 2, 49-58.

Державний стандарт початкової освіти. (2018). Взято з https:// zakon.rada.gov.ua/laws/show/872018-\%D0\%BF

Про освіту. (2017). Закон України. Взято $3 \mathrm{https}: / /$ zakon.rada.gov.ua/laws/show/ 2145-19

Концепція "Нова українська школа". Взято 3 https://osvita.ua/ legislation/Ser_osv/54258/

Кучеренко, І. А. (2014). Кредо вищої освіти - формування професійної компетентності вчителясловесника нової формації. Педагогічні науки: теорія, історія, інновачійні технології, 3, 128-134.

Ничкало, Н. Г. (2001). Неперервна професійна освіта як філософська та педагогічна категорія. Неперервна професійна освіта: теорія і практика, 1, 9-22.

Фенцик, О. (2018). Зміст і структура лінгвометодичної компетентності майбутнього вчителя початкових класів. Науковий вісник Мyкачівського державного універcumemy, 1 (7), 200-203. Doi 10.31339/ 2413-3329-2018-1(7)-200-203

Хомич, Л. О. (1998). Професійно-педагогічна підготовка вчителя початкових класів. Київ : Магістр-S.

Хоружа, Л. Л. (2004). Теоретичні засади формування етичної компетентності майбутніх учителів початкових класів (Автореф. дис. дра пед. наук). Київ.

\section{REFERENCES}

Bondar, V., Shaposhnikova, I. (2015). Upravlinnia pidhotovkoiu uspishnoho vchytelia: teoriia i praktyka. Kyiv : NPU Draghomanova.

Budnik, O. (2014). Theoretical Concepts of Preparing Future Teachers for Social and Pedagogical Activities in the First Grade School. Pedahohika $i$ psykholohiya profesiynoyi osvity, 2, 49-58.

Derzhavnyj standart pochatkovoji osvity. (2018). Retrieved from https:// zakon.rada.gov.ua/laws/show/872018-\%D0\%BF

Pro osvitu. (2017). Zakon Ukrayiny. Retrieved from https:// zakon.rada.gov.ua/laws/show/2145-19

Koncepcija "Nova ukrajinsjka shkola". Retrieved from https:// osvita.ua/legislation/Ser_osv/ 54258/

Kucherenko, I. (2014). Kredo vyshhoji osvity - formuvannja profesijnoji kompetentnosti vchytelja-slovesnyka novoji formaciji. Pedagogical science: theory, history, innovational technologies, 3, 128-136.

Nichkalo, N. G. (2001). Continuing Professional Education as a Philosophical and Pedagogical Category. Neperervna profesiyna osvita: teoriya i praktyka, 1, 9-22.

Fencyk, O. (2018). Zmist i struktura linghvometodychnoji kompetentnosti majbutnjogho vchytelja pochatkovykh klasiv. Naukovyj visnyk Mukachivsjkogho derzhavnogho universytetu. Pedaghoghika ta psykhologhija, 1 (7), 200-203. Doi 10.31339/2413-33292018-1(7)-200-203

Khomich, L. O. (1998). Profesiyno-pedahohichna pidhotovka vchytelya pochatkovykh klasiv. Kyiv : Master-S.

Khoruzha, L. L. (2004). Theoretical bases of formation of ethical competence of future primary school teachers. (Avtoreferat dysertatsii doktora pedaghoghichnykh nauk). Kyiv.

Стаття надійшла 15.03.2020 p. 